\title{
COMMENTS
}

\section{Derivative Actions by Policyholders on Behalf of Mutual Insurance Companies}

\author{
Theodore Allegaert $\dagger$
}

During the years 1990 through 1993, several of the largest domestic mutual insurance companies engaged in deceptive marketing and sales practices in their efforts to increase sales of their life insurance products. They sought to tap the mutual fund and savings bank markets by inducing individuals in specifically identified occupations who were likely to possess investment capital, but not investment acumen, to buy life insurance policies as "investment" or "retirement" plans. ${ }^{1}$ In doing so, agents styled themselves investment specialists, assiduously avoided using the word "insurance," and reaped a bonanza in commissions. ${ }^{2}$ Such misleading sales practices, however, were patently in violation of state consumer protection laws and insurance disclosure rules imposed by state insurance regulators. ${ }^{3}$

$\dagger$ B.A. 1987, Columbia University; J.D. Candidate 1996, The University of Chicago.

- See Michael Quint, New Refunds for Misled MetLife Customers, NY Times D1, D1 (Dec 28, 1993) (discussing the Metropolitan Life Insurance Company's involvement in such practices); Suzanne Woolley and Gail DeGeorge, Policies of Deception? Investigations of Misleading Sales Tactics Rock the Insurance Industry, Bus Week 24, 24-25 (Jan 17, 1994) ("Insurance agents [are] competing with banks, mutual funds and others.").

2 See Greg Steinmetz, Florida Widens Insurance-Sales Probe To New York Life, Possibly Prudential, Wall St J A3, A3 (Dec 29, 1993). These commissions can be up to twenty-seven times higher for whole life insurance policies than for more investment-like products such as annuity contracts. See Woolley and DeGeorge, Policies of Deception?, Bus Week at 24-25 (cited in note 1).

3 Steinmetz, Florida Widens Insurance-Sales Probe, Wall St J at A3 (cited in note 2); Greg Steinmetz, Met Life Got Caught; Others Sent Same Letter, Wall St J B1, B1 (Jan 6, 1994). 
When these practices came to light in 1993, state investigators believed that a small number of rogue agents at the Metropolitan Life Insurance Company's regional office in Tampa, Florida were responsible. During the ensuing months, however, a widespread scandal rocked the insurance industry, as investigators discovered that several of the largest insurers had engaged in similar misleading practices. ${ }^{4}$ Investigations in at least twenty-eight states, sizable fines, and numerous dismissals of regional managers followed. ${ }^{5}$ The companies involved initially sought to contain the damage by claiming that upper-level management was unaware of any illegal conduct. The evidence, however, belied such claims. ${ }^{6}$ Regulators determined that upper-level managers bore responsibility for the illegal practices, primarily for their failures to control and monitor their sales forces. ${ }^{7}$

Among the many issues raised by the scandal, the question stands out: What checks effectively constrain the management of mutual insurance companies? More specifically, should administrative regulation by state insurance departments be the sole check on mutual insurance company managers, or may policyholders act as private attorneys general and sue derivatively to redress breaches of duty by management?

This Comment examines whether, and on what legal basis, policyholders in mutual insurance companies have standing to bring derivative claims ${ }^{8}$ to enforce management duties and compel the proper use of corporate assets. ${ }^{9}$ The issue of policyholder

- See Woolley and DeGeorge, Policies of Deception?, Bus Week at 24 (cited in note 1) ("From a seemingly isolated incident in Florida, the MetLife scandal just keeps getting bigger."); Prudential in Talks on Accusations Some Customers Were Misled, NY Times Section 1 at 36 (Feb 17, 1996) (reporting that Prudential brokers were accused of luring customers into replacing existing policies at an added cost, a practice known as churning).

5 See Prudential in Talks, NY Times Section 1 at 36 (cited in note 4).

- See Woolley and DeGeorge, Policies of Deception?, Bus Week at 25 (cited in note 1).

7 Id at 24-25.

8 A derivative action aims to make the damaged company whole after management's breach of duty causes loss, irrespective of whether state regulators take action in response to the breach. Derivative litigation provides an alternative to state administrative regulation but, as will be discussed, is not without drawbacks.

9 A policyholder derivative action is functionally equivalent to the traditional stockholder derivative action: in each case, the plaintiff sues in the company's name to compel an accounting for losses resulting from director misconduct. The stockholder derivative action has traditionally been available whenever the company itself has refused to bring suit, particularly when the board is controlled by the directors who would be defendants in such a suit. Thus, derivative actions are distinct from direct actions against the company or its directors. See, for example, Koster $v$ (American) Lumbermens Mutual Casualty Co., 330 US 518, 522 (1947) ("Equity therefore traditionally entertains the derivative or secondary action by which a single stockholder may sue in the corporation's right when he 
standing is important both because mutual insurance companies manage great volumes of assets and because state regulation in its current form may not adequately protect policyholders from managerial wrongdoing.

The question of policyholder derivative standing first arose in the late nineteenth century. Since then, a judge-made rule in favor of standing has evolved in several jurisdictions. Although several cases support policyholder standing as a matter of common law right, statutory changes have complicated the issue. Specifically, a majority of states have enacted laws providing for derivative actions by "shareholders"10 without indicating whether mutual insurance policyholders fall within the meaning of the term. In addition, New York-where a number of the largest mutual companies are chartered ${ }^{11}$ and where much of the early case law supporting policyholder standing developed-appears to have enacted a statutory bar to policyholder derivative actions. ${ }^{12}$ However, because no court has ever cited, much less examined, the New York statute in a reported case, the prohibition remains untested.

Section I of this Comment briefly explains mutual insurance and its underlying legal framework. It focuses first on the duties that mutual companies and their managers owe to policyholders, and then on the authority of state regulators to oversee the insurance industry. Section II examines state and federal cases in which policyholders have sued derivatively, summarizes the statutory law governing derivative actions generally, and discusses derivative actions by nonstockholder plaintiffs in other contexts. Section II demonstrates that a combination of legislative inattention and a failure on the part of the judiciary to confront standing issues unique to mutual insurance derivative suits ${ }^{13}$

shows that [it] ... has refused to pursue a remedy.").

${ }_{10}$ See Deborah A. DeMott, Shareholder Derivative Actions Law \& Practice § 4:02 at 9-30 (Clark Boardman Callaghan 1987 \& Supp 1995) (citing state statutes). Although Professor DeMott's practice manual is the authoritative guide to derivative actions, she does not address the issue of mutual policyholder standing in the current edition.

${ }^{11}$ See Best's Insurance Reports: Life-Health 638, 1306, 1505 (Best 77th ed 1982) ("Best's Reports") (Metropolitan Life Insurance Company, Equitable Life Assurance Society of the United States, and New York Mutual Life Insurance Company-the second, third, and sixth largest mutual companies, respectively-are organized under the laws of New York. Each does business in the fifty states and Canada.).

${ }_{12}$ NY Ins Law $\S \S 108(a), 108$ (d) (McKinney 1985 \& Supp 1996) (providing that while the New York Business Corporation Law generally applies to insurance companies, certain articles and sections-including $\S 626$, which provides for shareholder derivative suits, see NY Bus Corp Law § 626 (McKinney 1986 \& Supp 1996)-shall not apply to mutual insurance companies).

${ }^{13}$ These issues include the policyholders' attenuated ownership interest in their 
has led to an unsatisfactory legal framework, in which courts in most jurisdictions may plausibly decide the issue either way. This is problematic because the current case law-which generally assumes standing without discussion and so does not resolve the issue - may encourage parties to settle for strike-suit ${ }^{14}$ money rather than risk litigating the standing issue. ${ }^{15}$ As in the stock corporation context, such collusive settlements nullify the salutary effects of derivative litigation.

Finally, Section III argues that while the issue of policyholder standing is closer than the cases indicate, courts should allow policyholder derivative suits to proceed, subject to certain limitations. Judicial and legislative decision makers should apply some, but not all, of the procedural safeguards against vexatious derivative claims that have evolved in the stock corporation context. ${ }^{16}$ These strictures should be made expressly applicable to policyholder suits, mutatis mutandis, whether by statute, rules of procedure, or judge-made court rules. Although the ideal solution may be legislative reform, until legislatures expressly provide for policyholder derivative standing, judges should add clarity to this area of the law by squarely confronting the differences between stockholder and policyholder actions when the latter arise. By analyzing mutual insurance companies' ownership structure, inquiring whether the policyholder's ownership interest necessar-

company, a lack of statutory provisions for policyholder suits, a lack of statutory protection from policyholder strike suits, and the level of state regulation of the insurance industry.

14 A strike suit is a derivative action brought with a view to winning a private settlement (consisting mostly or entirely of attorneys' fees) that does not intend to benefit the company on whose behalf the suit is brought.

15 Practical considerations may explain the paucity of case law addressing the standing issue in the mutual insurance context. The actual litigants, plaintiffs' lawyers on one side and director and officer insurance carriers ("D \& 0 carriers") on the other, have not pressed judges to decide the issue because both benefit from the uncertainty. Plaintiffs' lawyers certainly will not make an issue of it. It is, moreover, unlikely that any defendant will litigate the standing issue vigorously in a jurisdiction where the question is unsettled: If a defendant (represented by his D \& $O$ carrier) presses the issue and prevails, he wins the instant case, but risks a legislative response-perhaps in the wake of a well publicized dismissal on standing grounds of a meritorious case-giving policyholders standing by statute. This would haunt defendant D \& O carriers in the form of higher settlement payouts, because the credibility of the next plaintiff's threat to go trial would be greatly enhanced. If, on the other hand, a defendant presses the issue and loses, the ambiguity-which previously worked in its favor in settlement discussions-would be lost and policyholder standing would be enshrined in a published case report. See DeMott, Shareholder Derivative Actions $\S 7: 05$ at 27-28 (cited in note 10) (conflicts among plaintiffs and their attorneys).

${ }^{16}$ Such strictures include, among others, those enumerated in FRCP 23.1. See text accompanying notes 133-39. 
ily confers a right to sue derivatively, and examining the level and effectiveness of state insurance regulation, courts can effectively define the proper scope of policyholder derivative standing.

\section{THE FUNCTION AND REgULATION OF MUTUAL INSURANCE COMPANIES}

\section{A. Function}

Understanding the relationship between mutual insurance policyholders and their companies is essential to resolving the question of whether policyholders have standing to sue derivatively. Mutual insurance companies are organized, maintained, and operated solely for the benefit of their policyholders, who are insured individually while acting collectively as insurers. ${ }^{17}$ Such companies do not generate traditional entrepreneurial profits, ${ }^{18}$ but rather seek to meet their obligations at the lowest possible cost to the policyholders who, by paying premiums, provide the companies' exclusive source of capital. Any surplus beyond a reasonable reserve is distributed periodically among the policyholders as "dividends," usually in the form of a downward adjustment of future premiums. ${ }^{19}$ This mode of operation is intrinsically different from that of stock corporations (including stock insurers) ${ }^{20}$ not-for-profit corporations, ${ }^{21}$ and limited partnerships. ${ }^{22}$ Mutual companies are not dissimilar to cooperatives,

17 See, for example, Pennsylvania Mutual Life Insurance Co. v Lederer, 252 US 523, 533 (1920) ("[M]utual life insurance companies ... perform[ ] the service called insuring wholly for the benefit of their policyholders."); NY Ins Law § 1211 (McKinney 1985 \& Supp 1996) ("Every domestic mutual insurance corporation shall be organized, maintained and operated for the benefits of its members as a non-stock corporation.").

${ }_{18}$ See Fidelity \& Casualty Co. of New York v Metropolitan Life Ins. Co., 42 Misc $2 \mathrm{~d}$ 616, 248 NYS2d 559, 566 (NY Sup Ct 1963) ("[A] mutual company . . . functions to provide insurance at cost rather than to amass profits in the ordinary business sense.").

19 Id.

${ }^{20}$ Stock insurers, like other stock corporations, actively seek to generate profits for their shareholders and do not rebate surplus to policyholders. Robert $E$. Keeton and Alan I. Widiss, Insurance Law: A Guide to Fundamental Principles, Legal Doctrines, and Commercial Practices $\$ 2.1$ at 33 (West 1988).

${ }^{21}$ Not-for-profit corporations are necessarily barred from distributing profits or surplus to members. See, for example, Colo Rev Stat Ann $\S$ 7-24-110 (West 1990 \& Supp 1995); Iowa Code Ann § 504A.26 (West 1991 \& Supp 1995); RI Gen Laws § 7-6-31 (Michie 1992 \& Supp 1995). Moreover, membership in certain not-for-profit corporations may not involve the right to vote. See Henry B. Hansmann, Reforming Nonprofit Corporation Law, $129 \mathrm{U} \mathrm{Pa} \mathrm{L}$ Rev 497, 503 (1981) (noting that some nonprofit organizations are not controlled by their patrons). Policyholders generally have a right to vote in the management of mutual insurance companies. See note 23.

${ }_{22}$ See, for example, Lubin v Equitable Life Assurance Society, 326 Ill App 358, 61 NE2d 753, 757 (1945) ("It has been uniformly and repeatedly held that a mutual life 
which provide goods or services to members at cost and give each member substantially equal control. ${ }^{23}$

The relationship between mutual insurance policyholders and their company defies easy classification because the policyholders are both the equitable owners of the company and, at the same time, akin to creditors of the company. This relationship differs from that between a stockholder and his corporation in important ways. Because "dividends" in the mutual insurance context represent an adjustment of policy premiums rather than a return on equity, ${ }^{24}$ the policyholder has little interest in the continued growth and prosperity of the enterprise beyond assurance of the company's ability to meet its contractual obligations to him. This relationship has been likened to that of debtor and creditor, where the buyer has merely prepaid for the service he seeks from the vendor. ${ }^{25} \mathrm{By}$ this view, the policyholders are not "owners" who can be relied on to use derivative suits to safeguard the ongoing prosperity of the company. Rather, they are creditors whose interests extend no further than the receipt of a contractually determined payout (usually following some misfortune) or a contractually determined refund if the company elects to rebate yearly surplus or cancel the policies outright (as it may). ${ }^{26}$

The debtor-creditor analogy underscores the differences between policyholders and stockholders as they relate to questions of derivative standing. If a court views policyholders as more like creditors than owners, it should apply the traditional rule barring derivative actions by creditors on behalf of solvent companies. ${ }^{27}$ This rule assumes that creditors will be unduly skeptical

insurance company does not partake of the nature of a partnership.").

${ }^{23}$ See generally Israel Packel, The Organization and Operation of Cooperatives 2-3 (ALI 1970). See also J.A.C. Hetherington, Fact v. Fiction: Who Owns Mutual Insurance Companies, 1969 Wis L Rev 1068, 1080 ("The general rule is that each policyholder [in a mutual insurance company] has one vote regardless of the number of policies held and regardless of its or their value."). Professor Hetherington differentiates cooperatives from mutual insurers, however, by noting that the "strong tradition of participation among members [of some cooperatives]" is not shared by mutual insurance policyholders. Id at 1083 n 56.

${ }_{24}$ See, for example, Kern v John Hancock Mutual Life Insurance Co., 8 AD2d 256, 186 NYS2d 992, 996 (1959) ("While the annual return to the policyholder . . . is generally called a 'dividend', it is not analogous to the distribution of profits to stockholders of a profit-making organization.").

${ }^{25}$ See Hetherington, 1969 Wis L Rev at 1072 (cited in note 23) ("As a buyer who paid in advance, the policyholder is a 'financing buyer,' a creditor of the insurer.").

${ }^{26}$ See id at 1076 ("The fact that policyholders in a mutual insurance company ... may be 'fired' by the management who are theoretically their employees, is strongly indicative of the nonproprietary character of their relationship to the company.").

${ }^{27}$ See, for example, ALI, 2 Principles of Corporate Governance: Analysis and Recom- 
(relative to investors) of normal business risks because they care only that their debtors remain able to pay. That is, policyholders, like simple creditors, arguably are not interested in the growth or other benefits that management expects to realize when it incurs added risks. By this view, policyholders will be more inclined to bring vexatious derivative actions alleging that management decisions are "harming" the company. ${ }^{2 B}$ Although the problem of characterizing the policyholders' relationship to their company is pivotal in mutual insurance cases, it has yet to be squarely addressed in a judicial opinion resolving a policyholder action. ${ }^{29}$ Thus the applicability of the rule against creditor suits to policyholders is uncertain.

\section{B. Regulation}

Insurers differ from other private corporations in the level and intrusiveness of the regulation to which each is subject. States regulate insurance more than almost any other industry, due in part to a near total absence of federal insurance regulation. ${ }^{30}$ All states have insurance departments ${ }^{31}$ charged with supervising and regulating the insurers chartered and doing business in their respective states. The departments are headed by insurance commissioners ${ }^{32}$ who generally have broad statutory authority to redress illegal activity by insurers and insurance agents. Commissioners may impose fines, issue injunctions, remove managers, and, in egregious cases, revoke an offending company's license to conduct business. ${ }^{33}$ In the case of insolvent or recalcitrant insurers, commissioners generally have broad and

mendations § 7.02(a) at 33-34 \& comment $\mathrm{c}$ at $35-36$ (1994).

${ }^{28}$ Id ("This ... rule [prohibiting creditor derivative suits against solvent corporations] protects corporate officials from exposure to litigation brought by creditors who would rationally have a ... more skeptical attitude toward business risks than shareholders, and it is also justified by the greater availability to creditors of contractual mechanisms by which to ... enforce their rights.").

20 See text accompanying notes 56-75.

${ }^{30}$ See Keeton and Widiss, Insurance Law $\S 8.4(a)(3)$ at 958-61 (cited in note 20) (noting that the McCarran-Ferguson Act of 1945 exempted the insurance industry from federal regulation and antitrust laws, except in cases of boycotts or restraints of trade).

${ }^{31}$ See Best's Reports at vi (cited in note 11) (listing officials in charge of insurance affairs in all states).

${ }^{32}$ Various states give these officials the title of commissioner, superintendent, or director of insurance. Id. Since their professional association is styled the National Association of Insurance Commissioners ("NAIC"), this Comment generally uses "commissioner" to describe all such officials.

${ }^{33}$ See generally Werner Pfennigstorf, The Enforcement of Insurance Laws, 1969 Wis L Rev 1026. 
exclusive powers of rehabilitation, including the authority to assume control as statutory receiver. ${ }^{34}$ Fines and restitution, however, appear to be the tools of choice for many insurance commissioners. ${ }^{35}$

In the wake of illegal conduct, large fines assessed by multiple states ${ }^{36}$ coupled with a loss of business from attendant bad press, may substantially weaken an insurance company. In the case of a mutual insurer, the policyholders, who effectively own the company, must bear such losses. Where losses are caused by a breach of duty on the part of the management, policyholder standing is the first issue an inquiring plaintiff's lawyer will need to address. Whether policyholders may sue corporate directors and officers derivatively on behalf of a damaged, but not insolvent, insurer will be of considerable moment to the directors and officers of mutual companies, their liability insurance carriers, the policyholders, and, of course, the plaintiffs' bar.

\section{LEGAL BACKGROUND}

\section{A. Introduction}

Policyholder derivative suits have proceeded on three bases: common law precedent, statutes, and Federal Rule of Civil Procedure 23.1 (or state rules patterned on it). This Section addresses each in turn, beginning with the common law precedents-the most instructive of which predate the statutes and Rule 23.1.

While there is ample precedent for allowing policyholder derivative actions to proceed, judicial opinions resolving such actions have largely failed to consider the standing issue. This fact, coupled with the advent of numerous laws giving a right of action to "shareholders," renders the present legal framework for policyholder suits unsatisfactory. In the thirty-odd states with substantive provisions for stockholder derivative suits, a defendant may plausibly assert that the legislature has elected to regulate derivative actions by statute, and has declined to extend a derivative cause of action to policyholders. ${ }^{37}$ If they accepted

${ }^{34}$ See Keeton and Widiss, Insurance Law $\S 8.2(a)$ at 940 (cited in note 20) (listing examples of statutes providing for rehabilitation of insurers). See also NY Ins Law \$ 7409 (McKinney 1985 \& Supp 1996) (authorizing receiver to seize all of the insurer's assets).

${ }_{35}$ See Pfennigstorf, 1969 Wis L Rev at 1039-44 (cited in note 33) (discussing use of fines).

${ }^{36}$ MetLife and others faced this situation in the recent scandals. See text accompanying notes 1-5.

${ }_{37}$ This assertion is strongest in states that have statutes giving derivative standing 
this argument, courts could reasonably construe such statutes strictly and conclude that, given the extensive state regulation of the industry, these statutory provisions do not mean more than they say..$^{38}$

The case law, however, suggests the opposite result. Virtually all judicial opinions in insurance derivative actions after the Supreme Court's 1947 decision in Koster $v$ (American) Lumbermens Mutual Casualty $\mathrm{Co}^{39}$ have merely assumed the cause of action without explicitly addressing standing. Thus, interested parties remain uncertain as to how a court will rule if and when the standing issue is litigated.

The relationship between mutual insurance policyholders and their company derives historically from statutes under which mutual companies are chartered and from the contractual terms of issued policies. ${ }^{40}$ Incident to membership in a mutual company, the policyholder acquires certain proprietary interests, yet these interests are not fiduciary and certainly are not akin to partnership. In addition, membership places the policyholders in a creditor-like contractual relationship with the company. ${ }^{41}$ The challenge in adjudicating a mutual insurance derivative action, then, is to determine whether the proprietary interests should eclipse the debtor-creditor elements of the relationship.

to nonstockholders other than policyholders. See, for example, NY Not-for-Profit Corp Law § 623(a) (McKinney $1970 \&$ Supp 1996) (providing that any class of members, capital certificate holders of record, or owners not of record of a not-for-profit corporation may sue); Cal Corp Code $\$ \S 5710,7710$ (West 1990 \& Supp 1996) (providing that subject to limitations, plaintiffs may sue public benefit corporations and mutual benefit corporations, respectively, if they were members at the times of the disputed transactions).

${ }_{33}$ Clarifying language, if any, in state statutes does not mention policyholders specifcally. See, for example, Va Code Ann § 13.1-603 (Michie 1993 \& Supp 1995) ('Shareholder' [as used in the Virginia Stock Corporation Act] means the person in whose name the shares are registered in the records of the corporation [or] the beneficial owner of shares ...."); Cal Corp Code $\S 800$ (a) (West 1990 \& Supp 1996) ("As used in this section, ... 'shareholder' includes a member of an unincorporated association.").

30330 US 518 (1947). See text accompanying notes 67-75.

to See Fidelity \& Casualty Co. of New York v Metropolitan Life Ins. Co., 42 Misc 2d 616, 248 NYS2d 559, 565-67 (NY Sup Ct 1963) (citing statutes and noting that statutes define policyholders' rights to share in the proceeds and prescribe manner in which mutual company must ascertain and distribute divisible surplus to policyholders). See also Lubin v Equitable Life Assurance Society, $326 \mathrm{Il}$ App 358, 61 NE2d 753, 756 (1945) ("[T]he rights of [policyholders] all stem from their policies ... [which] constitute the whole contract between the parties."), quoting Andrews $v$ Equitable Life Assurance Society, 124 F2d 788, 789 (7th Cir 1941).

"Fidelity \& Casualty, 248 NYS2d at 565 (stating that "the policyholder acquires certain specified proprietary interests [in the company] but, apart from these, the relationship is not of a fiduciary nature [and] is essentially that of debtor and creditor measured by the contractual terms of the policy"). 


\section{B. Common Law Recognition of Policyholder Standing}

The applicability of debtor-creditor analysis to the relationship is complicated by the trustee-like characteristics of certain activities undertaken by the company, such as collecting premiums (which are generally prepaid) and managing company funds. ${ }^{42}$ Recognizing these characteristics, equity courts began to soften the application of the harsh debtor-creditor rule $e^{43}$ when adjudicating certain policyholder actions. Courts still refused to recognize a fiduciary duty in direct actions by policyholders (such as suits seeking to recover on policies or suits in equity for an accounting) ${ }^{44}$ but began to ignore the rule in actions by policyholders on behalf of their company, such as to enjoin waste. ${ }^{45}$

\section{Early cases.}

Of approximately two dozen reported cases in which policyholders have sued derivatively, ${ }^{46}$ two early New York appellate cases stand out for their trenchant, albeit incomplete, analyses of mutual insurance issues that later opinions have avoided. Ironically, neither was a purely derivative suit by a mutual insurance policyholder.

The first, Swan $v$ Mutual Reserve Fund Life Association, ${ }^{47}$ was brought as a direct action (notwithstanding its derivative character) against the insurer for an accounting in equity and to

${ }^{42}$ See William M. Shernoff, Sanford M. Gage, and Harvey R. Levine, Insurance Bad Faith Litigation $\S 1.05$ at 1-18 to 1-20 (Matthew Bender 1996).

43 The rule deeming the debtor-creditor relationship nonfiduciary was originally applied in the insurance context by the New York Court of Appeals in Uhlman v New York Life Insurance Co., $109 \mathrm{NY}$ 421, 17 NE 363 (1888). The Uhlman court held that the policyholders of insurance companies could not sue the company directly and thereby "place the company in the power of unscrupulous parties [who could] take advantage of it for the purpose of endeavoring to levy contribution from it." Id at 368.

44 See, for example, Lubin v Equitable Life Assurance Society, 326 Ill App 358, 61 NE2d 753, 757-58 (1945) (noting that a mutual life insurance company is not like a partnership).

${ }_{45}$ See Young $v$ Equitable Life Assurance Society, 49 Misc 347, 99 NY 446, 456 (NY Sup Ct 1906) (holding that as a certificate holder, plaintiff could compel corporation to collect assets from delinquent directors).

16 Parties tend to settle derivative suits, so the number of reported cases is a poor reflection of the frequency of derivative complaints in either the corporate or insurance contexts. See Thomas M. Jones, An Empirical Examination of the Resolution of Shareholder Derivative and Class Action Lawsuits, 60 BU L Rev 542, 544-45 (1980) (finding that plaintiffs obtained a settlement without a definitive judicial ruling in over 70 percent of 531 actions studied, and that in less than 1 percent of the cases did plaintiffs win a litigated judgment).

17155 NY 9, 49 NE 258 (1898). 
enjoin waste and diversion of corporate assets. The court held that (then) Section 56 of the New York Insurance Law ${ }^{48}$ precluded the plaintiff from maintaining the action and that such an action could be brought only by the attorney general, if at all. In its analysis, the Swan court underscored the differences between stock and mutual companies, described mutual insurance companies as being "almost public in their nature," and defended the prescribed remedy as being in keeping with the view that insurance companies should be "the especial objects of the care and watchfulness of the state." Swan thus appears to be the only opinion to consider explicitly the operative differences between a policyholder and a stockholder and to assess the effect of state regulation on the policyholder's right to sue to protect the company. Later opinions resolving policyholder actions have ignored these important issues.

Young $v$ Equitable Life Assurance Society ${ }^{50}$ involved an action similar to Swan, but brought derivatively against Equitable's directors and officers. In overruling a demurrer to the policyholder's derivative complaint ${ }^{51}$ alleging waste of corporate assets and other management wrongdoing, the Young court emphasized the similarities between stockholders and policyholders. Focusing on the plaintiff's rights as a policyholder, the court stated:

It seems . . . clear that, in a purely mutual company, the whole body of policy holders ... . have a quasi ownership in all the assets of the corporation, and are, like stockholders of

48 At the time, Section 56 of the Insurance Law provided, in part, that: "[N]o order, judgment or decree, providing for an accounting or enjoining, restraining, or interfering with the prosecution of the business of any life or casualty insurance company ... shall be made or granted otherwise than upon the application of the attorney general, on his own motion or after his approval of a request in writing of the superintendent of the insurance department." See id at 261 (quoting the provision). Other jurisdictions later enacted similar statutes. See Haynes $v$ Fraternal Aid Union, 34 F2d 305, 306 (D Kan 1929) (noting that under 1927 Kan Sess Laws ch 231, $\S 40-713$, insurance companies must ask the attorney general to seek an injunction); Schwartz $v$ Kemper, 69 F Supp 152, 153 (N D Ill 1946) (noting that under Ill Ann Stat ch 73, II 813 (Smith-Hurd 1965), the attorney general must petition for injunction).

(9) Swan, $49 \mathrm{NE}$ at 261-62.

so 49 Misc 347, 99 NYS 446 (NY Sup Ct 1906), aff'd as Young $v$ Hyde, 112 AD 760, 98 NYS 1052 (1906).

${ }^{51}$ The plaintiff policyholder was also a stockholder. Equitable, which is now a New York-chartered mutual company, was then a stock corporation with its business "conducted upon the mutual plan." Young, 99 NYS at 447. This transitional phase preceded its full mutualization in 1925, when the company retired the last of its capital stock. See Best's Reports at 638 (cited in note 11). 
an ordinary corporation, in effect its cestui que trust. The membership changes hourly. Old members go out and new come in; but, unless all the policy holders at a given moment in equity own the corporate property, then we have the extraordinary spectacle of a corporation, without members, without stockholders, a legal fiction, an abstract idea, owning absolutely all corporate property, in trust for no one, with responsibility to no one except creditors and then only to pay debts. This conception of a legal fiction as an absolute owner is not sound. Living persons must be the ultimate owners of all corporate property. In a mutual insurance company they can be none other than the policy holders. ${ }^{52}$

The court explained that the stockholder's right to sue derivatively is not based upon the relationship-fiduciary or otherwise-between stockholders and directors. ${ }^{53}$ Rather, courts of equity recognize the derivative form of action because corporate directors are held to the standard of a trustee in fulfilling their fiduciary duties to the corporation. The court concluded that the policyholder "has an interest in the corporate funds, and a right to compel proper management and the collection of assets diverted, precisely as an ordinary stockholder has that right."54 This analysis, while cogent, remains incomplete for having skirted the debtor-creditor issue.

Thus, the Young court diverged from Swan in holding that the statutory bar to private actions seeking orders, judgments, or decrees that "interfere" with insurance companies was inapplicable to derivative actions. Courts in other jurisdictions, applying similar statutes, subsequently held likewise. ${ }^{55}$ These rulings signify that insurance commissioners possess a nonexclusive power to police the industry. Acceptance of this proposition is pivotal in any insurance policyholder derivative suit, yet it has been virtually ignored in contemporary judicial opinions on the subject. Moreover, neither the early nor the later cases adequately answer standing concerns raised by the creditor-like expectations of the mutual policyholder.

62 Young, 99 NYS at 455 (emphasis added).

63 See id (observing that directors and stockholders are not technically trustees).

64 Id at 455-56.

65 See, for example, Haynes, 34 F2d at 307-08; Winger $v$ Chicago City Bank \& Trust Co., 394 Ill 94, 67 NE2d 265, 272 (1946). 


\section{Modern case law.}

Unlike the early opinions, modern cases do not provide even partially satisfying analyses concerning policyholder standing to sue derivatively. To the extent that courts consider standing, they tend to assume it summarily and move on to other issues.

Modern treatment of policyholder standing begins with Koster $v$ (American) Lumbermens Mutual Casualty Co. ${ }^{56}$ Koster is noteworthy for at least two reasons: first, it exemplifies judicial conflation of policyholder and stockholder actions; second, it is the only derivative suit by a mutual insurance policyholder to reach the Supreme Court. At the outset of Koster, the district court, despite the plaintiff's portrayal of the case as a stockholder derivative suit, ${ }^{57}$ noted that "[t]he plaintiff is not a stockholder-he is a policyholder." The court concluded that the suit involved the affairs of an out-of-state, or "foreign" corporation, ${ }^{59}$ and that that fact, coupled with issues of convenience to parties and witnesses, warranted dismissal. ${ }^{60}$ Thus, the lower court never directly resolved the implications of the plaintiff's policyholder status.

In affirming the district court's dismissal on forum non conveniens grounds, both the Second Circuit and the Supreme Court acknowledged standing by implication. The Second Circuit noted that while Illinois law on the subject of policyholder standing "is not wholly clear[,] ... we see no valid distinction between a stockholder's and a policyholder's derivative suit seeking relief of this character." ${ }^{31}$ The Supreme Court, in turn, conflated the two varieties of derivative action by cursory analogy: "The stockholder's derivative action, to which this policyholder's action is analogous, is an invention of equity ...."

Koster is known as a forum non conveniens case. However, had the trial court pushed its analysis one step further, the case could have been dismissed on standing grounds. The district court stated vaguely that Illinois's regulatory statutes allowed only the director of insurance to bring certain actions affecting

s6 64 F Supp 595 (E D NY 1945), aff'd, 153 F2d 888 (2d Cir 1946), aff'd, 330 US 518 (1947).

${ }^{87}$ Id at 597.

ss Id. Plaintiff Koster, a New York policyholder in an Illinois mutual insurance company, alleged waste and self-dealing by Kemper, an officer of the company. Id at 596.

so That is, chartered under the laws of a state other than the forum state.

${ }^{60}$ Koster, 64 F Supp at 597-98.

61 Koster, 153 F2d at 890.

${ }^{2}$ Koster, 330 US at 522. 
insurance companies and that "[t]his may be of importance in view of the fact that the plaintiff has never communicated or made any complaint to the Insurance Department of the State of Illinois. ${ }^{\text {"63 }}$ Thus, although the appellate opinions in Koster flatly declared the case analogous to a stockholder action, the district court did consider insurance-specific state law issues, such as whether demand on the director of insurance was required. Indeed, as the Second Circuit remarked in a footnote, the district court in New York would not have declined jurisdiction but for the fact that Koster was a policyholder, not a shareholder in a stock corporation. ${ }^{64}$ It is somewhat ironic, therefore, that Koster is cited as authority for the application of the doctrine of forum non conveniens to "a shareholder's derivative action."

Other policyholder derivative actions contemporaneous with Koster expressly assumed standing but required demand on the state insurance commissioner as a prerequisite to the maintenance of a private action. ${ }^{66}$ These holdings marked a departure from the earlier cases holding that actions interfering with insurers must be brought by attorneys general (if at all), and this seems for a time to have been the trend.

Koster presaged a tendency of courts to pass over standing by cursory analogy to stockholder actions. The Illinois Appellate Court displayed this tendency in Lower $v$ Lanark Mutual Fire Insurance Co. ${ }^{67}$ The Lower court considered whether the plaintiff lost standing when the company declined to renew her policy during the course of the litigation. The appellate court affirmed the trial court's conclusion that the plaintiff "no longer had standing to maintain the shareholder's derivative action." ${ }^{\prime 68}$ In so doing, the Lower court did not hesitate to substitute "shareholder" for "policyholder" in its discussion, did not inquire whether the Illinois statute governing derivative actions permitted a poli-

Koster, 64 F Supp at 598.

64 Koster, 153 F2d at $890 \mathrm{n} 2$ ("[T] jurisdiction had this been a derivative suit by a shareholder in a stock corporation.").

${ }_{65}$ DeMott, Shareholder Derivative Actions $\S 4: 11$ at 83-85 (cited in note 10).

${ }_{66}^{6}$ See, for example, Shay $v$ Metropolitan Life Insurance Co., 172 Misc 202, 14 NYS2d 347,348 (NY Sup Ct 1939) (holding that policyholder must have exhausted other remedies before maintaining a derivative action); Clifford $v$ Metropolitan Life Insurance Co., 264 AD 168, 34 NYS2d 693, 696 (1942) (same).

151 Ill App 3d 471, 502 NE2d 838 (1986).

${ }^{68}$ Id at 840 . 
cyholder action, ${ }^{69}$ and did not discuss whether or how the director's regulatory power might bear on the case.

In Elgin v Alfa Corp, a recent case involving facts similar to Lower, the Supreme Court of Alabama reversed the trial court's grant of summary judgment in favor of the defendant directors and officers, which purportedly had been entered on standing grounds. ${ }^{70}$ Elgin is notable because it relaxed the traditional rule that a derivative plaintiff must be an equitable owner of the company at the time suit is brought. ${ }^{71}$ The opinion's emphasis on that procedural requirement, however, obscured the more basic question of standing. The court relegated the question of whether a policyholder ever has the legal capacity to bring a derivative action to a terse footnote, stating that "[i]t is undisputed that a policyholder in a mutual company can bring a derivative action on behalf of the mutual company." While "undisputed" may mean that the parties did not brief the issue ${ }^{73}$ it is also possible that, under the authorities cited, the court believed the conclusion indisputable. This would be surprising both because the issue had never before been considered in Alabama and because neither of the sources cited provide compelling authority

$\approx$ Id at $839-40$. See 850 ILCS 5/7.80 (1993) (providing for a derivative action by a shareholder who meets a contemporaneous ownership requirement, without specifying the scope of the term "shareholder").

70 598 S2d 807, 813 (Ala 1992). The Alabama Supreme Court excused Elgin from the contemporaneous ownership requirement. The court stated that the Alabama Rules of Civil Procedure require "that the plaintiff allege that he was a "shareholder or member at the time of the transaction of which he complains" and that this requirement "is referred to as ... 'contemporaneous ownership' or 'substantive standing." Id at 811-12, citing Ala $R$ Civ $P$ 23.1. The issue on appeal was whether the court should excuse the policyholderplaintiff from the contemporaneous ownership requirement because the company had declined to renew his policy in order to deprive him of standing. The court held that, although the plaintiff had no right to have the company renew his policy (and, hence, no direct cause of action for reinstatement), the plaintiff would be equitably excused from the contemporaneous ownership requirement because there was evidence that the company's reason for refusing to renew Elgin's policy was to negate his standing. Elgin, $598 \mathrm{~S} 2 \mathrm{~d}$ at 813. Although the ownership-at-filing requirement was not mandated by Ala R Civ P 23.1, it may have been pivotal in the decision. As the court stated, "[i]t is of considerable import to this determination that Elgin presented evidence that he was a policyholder with Alfa Mutual at the time of the disputed transactions." Id.

${ }^{71}$ Compare Lower, 502 NE2d at 840 (stating that a shareholder must retain ownership throughout pendency of action).

72 Elgin, 598 S2d at 811 n 3, citing Pomerantz v Clark, 101 F Supp 341 (D Mass 1951), and $43 \mathrm{Am}$ Jur $2 \mathrm{~d}$ Insurance $\S 73$ at 155 (1982). The Elgin opinion does not distinguish "substantive standing" qua contemporaneous ownership under Rule 23.1 from the more basic issue of whether, assuming contemporaneous ownership and all other adjectival requirements are satisfied, a policyholder has the same capacity to sue as a stockholder. See id at 811-14.

73 See note 15 for reasons the parties may not have briefed the issue. 
for the asserted proposition. ${ }^{74}$ Elgin is thus flimsy precedent: the opinion addresses neither the level and effectiveness of state regulation nor the differences in the relationship between stock and mutual companies and their members-issues that are vital to the standing inquiry. ${ }^{75}$

\section{The Statutory Framework for Mutual Insurance Derivative Actions}

1. Derivative actions by stockholders.

Professor DeMott, in her practice manual on derivative actions, cites thirty-six state laws providing for derivative actions by "one or more shareholders." ${ }^{\text {"76 }}$ In the remaining jurisdictions, the regulation of derivative actions is left to the courts. Of the states with substantive statutes, Connecticut provides a derivative cause of action to "shareholders or members" of corporations generally, ${ }^{77}$ Wisconsin has a statute tailored to nonstock corporations, ${ }^{78}$ and Pennsylvania gives policyholders standing in certain circumstances. ${ }^{79}$ That Wisconsin's legislature passed a law giving derivative standing to members of nonstock companies twenty years after it gave stockholders a statutory cause of action $^{80}$ implies that the stockholder provision did not extend be-

74 The first source cited by the Elgin court was Pomerantz, $101 \mathrm{~F}$ Supp at 345 (Plaintiff's rights to bring a derivative action "are parallel to a shareholder's rights to bring [such an] action.... [However,] [c]onceivably the laws ... that subject mutual insurance companies to supervision and correction by the insurance commissioner reduce ... the right of a minority member to bring [a derivative] suit. . . But this point need not be decided...."). The second was 43 Am Jur $2 d$ Insurance $\S 73$ at $155 \mathrm{n} 74$ (cited in note 72), which cites Huber $v$ Martin, 127 Wis 412, $105 \mathrm{NW} 1031$ (1906). Despite Am Jur's reliance on it, Huber may not have been good law since 1953, when the Wisconsin legislature accorded a derivative cause of action to shareholders of business corporations, but did not address policyholders of mutual insurance companies. See Wis Stat Ann $\S 180.0741$ (West 1992 \& Supp 1995). See also note 80.

${ }_{75}$ Other judicial opinions in policyholder actions have similarly failed to confront these countervailing issues. See, for example, Stoner $v$ Walsh, 772 F Supp 790, 795-96 (S D NY 1991) (assuming that general corporate law applies unless it conflicts with insurance law); Amabile $v$ Lerner, 74 NJ Super 443, 181 A2d 520 (1962) (disposing of summary judgment motions without even considering standing question).

${ }^{76}$ See DeMott, Shareholder Derivative Actions § 4:02 at 9-30 (cited in note 10).

77 Conn Gen Stat Ann \& 52-572j(a) (West 1991 \& Supp 1995).

${ }^{78}$ Wis Stat Ann $\S 181.295$ (West 1992 \& Supp 1995).

${ }^{79} 40 \mathrm{~Pa}$ Stat § 506.1(r) (Purdon 1992 \& Supp 1995) (establishing liability of insurance company officers and directors for losses occasioned by investments not authorized by the act).

so See Wis Stat Ann $\S \S 180.0741,181.295$ (stock company and nonstock company provisions respectively). George A. Hardy, Revisions of the Nonstock Corporation Law, Wis Bar Bull 21, 23 (June 1974) ("Section 13 establishes a statutory right in a member of a 
yond the stock corporation context; this may also be the case in the thirty other states that provide for shareholder actions by statute. Thus, the basis for a nonshareholder derivative suit in these jurisdictions remains unclear.

The New York statutory scheme governing derivative suits is more complete than most. ${ }^{81}$ It also appears to contain a statutory bar to derivative actions on behalf of mutual insurers. While the New York Business Corporation Law ("BCL") generally applies to insurance companies, ${ }^{82} \S 108(\mathrm{~d})$ of the New York Insurance Law ("Insurance Law") declares that certain articles and sections of the BCL shall not apply to mutual insurance companies. This exclusion includes BCL Article Six, which contains § 626 , the provision for shareholder derivative actions. ${ }^{83}$

That the New York legislature would amend its laws to deny policyholders a statutory basis for derivative suits-when the courts of that state have provided the richest vein of relevant case law-invites inquiry. The legislature passed Insurance Law $\S 108$ as part of a 1964 amendment that made the Insurance Law independent of other corporate law chapters. ${ }^{84}$ Although $\S 108$ states that BCL $\S 626$ does not apply to mutual insurers (and appears to override pre-1964 New York cases supporting policyholder derivative actions), subsequent cases suggest either that

[nonstock] corporation to bring a derivative action.") (emphasis added). One court, noting that Tennessee's similar statutory scheme does not clearly apply to a nonstockholder action, allowed the action to proceed under case precedents. Bourne $v$ Williams, 633 SW2d 469, 472 (Tenn Ct App 1981).

si See Harry G. Henn and Jeffery H. Boyd, Statutory Trends in the Law of Nonprofit Organizations: California, Here We Comel, 66 Cornell L Rev 1103, 1114-26, 1132-36 (1981).

82 See NY Ins Law \& 108(b)(1) (West 1985 \& Supp 1996) ("If any provision of the business corporation law conflicts with any provision of this chapter, the provision of this chapter shall prevail, and the conflicting provision of the business corporation law shall not apply.").

${ }^{83}$ NY Ins Law $\S 108(d)$. BCL $\S 626(a)$ provides: "An action may be brought in the right of a domestic or foreign corporation to procure a judgment in its favor, by a holder of shares or of voting trust certificates of the corporation or of a beneficial interest in such shares or certificates." NY Bus Corp Law § 626(a).

\& See New York State Legislative Annual, 1964 148:

[T]his amending bill adds . . . a bridge section' between the Insurance Law and the Business Corporation Law [now $\S 108$ ]. . . . However, certain provisions of the Business Corporation Law are excluded from applicability to insurers . . . as a continuation of the policy of this State in recognizing the specialized function of insurers, the close regulation of the insurance industry by the Superintendent of Insurance and the interest of the State in protecting the policyholders in this State. 
a policyholder may in fact sue in the face of $\S 108$ or merely that litigants have not pressed the issue. ${ }^{85}$

The 1964 amendments make no provision for derivative actions by the superintendent on behalf of solvent insurers. This is significant because the remedies traditionally provided by the superintendent are wholly different from the redress that derivative litigation seeks to provide. Whether this was a conscious omission or resulted from inadvertence cannot be gleaned from the legislative history, which generally suggests that exclusion of BCL provisions from application to insurers was consistent with state policy of "close regulation of the insurance industry by the Superintendent of Insurance." ${ }^{\$ 66}$ Nor does the legislative history indicate whether the state interest in regulating insurance companies emanates solely from the public interest in being free from primary harms caused by insurers, or whether it also derives from a policy of protecting mutual policyholders from management wrongdoing. New York's framework thus highlights the division between legislative and judicial treatment of the standing issue and further calls into question the judicial habit of assuming standing.

\section{Actions by nonstockholders in other contexts.}

Derivative actions by members of cooperatives and not-forprofit corporations and by limited partners provide instructive points of reference, since courts entertaining these suits have also relied on assumed standing, straight analogy to stockholder actions, or, less commonly, statutory authority. ${ }^{87}$

The mutual policyholder's predicament resembles that of a member of a cooperative or a nonprofit corporation. Despite a paucity of statutory authority, cooperative members generally have been accorded derivative standing. ${ }^{88}$ One notable difference

${ }_{85}$ The question of whether courts should read NY Ins Law $\$ 108(d)$ to disparage policyholders' common law right to sue derivatively has not been litigated; indeed, $\S$ 108(d) appears never to have been cited in a case report. For policyholder actions filed in New York since the passage of $\S 108$, see Garfield v Equitable Life Assurance Society, 7 Misc 2d 283, 164 NYS2d 819 (NY Sup Ct 1956); Garfield v Equitable Life Assurance Society, 205 NYS2d 758 (NY Sup Ct 1960). See also Stoner $v$ Walsh, 772 F Supp 790, 805 (S D NY 1991) (discussing individual liability of board members of mutual company).

${ }^{86}$ New York State Legislative Annual, 1964 at 148 (cited in note 84).

${ }_{87}$ There have been numerous other special-context derivative suits. See, for example, In re Sunrise Securities Litigation, 916 F2d 874 (3d Cir 1990) (depositors in mutual savings and loan); York Properties, Inc. $v$ Neidoff, 10 Misc 2d 439, 170 NYS2d 683 (NY Sup Ct 1957) (pledgee of corporate stock); Kauffman $v$ Dreyfus Fund, Inc., 434 F2d 727 (3d Cir 1970) (shareholder in mutual fund).

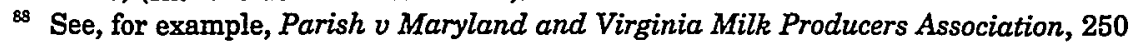


between cooperatives and mutual insurers, however, is that cooperatives enjoy a tradition of active management by members; ${ }^{89}$ this tradition renders derivative suits somewhat less suspect in that context. Likewise, although few jurisdictions expressly authorize derivative actions by members of nonprofit organizations, judges have occasionally let such suits proceed. ${ }^{90}$ Professor DeMott concludes that this state of affairs is probably a result of legislative inattention, ${ }^{91}$ since the states that have considered the issue do permit derivative suits by members of nonprofit corporations. Thus, malcontent cooperative members, nonprofit members, and mutual policyholders all face inconsistent statutory authority for derivative standing, some recognition of such standing in the case law, and (yet) inadequate policy analysis in the pertinent judicial opinions. ${ }^{92}$

Limited partnership law concerning derivative actions is more developed than the law in the cooperative, not-for-profit, and insurance areas. Most notably, the recent versions of the Revised Uniform Limited Partnership Act provide a limited partner with standing to sue on behalf of the partnership if the general partners have refused or are unlikely to agree to bring the action. ${ }^{93}$ This provision seems entirely appropriate in an era when limited partnerships routinely control vast assets and include large numbers of investors well removed from, and without personal knowledge of, the activities or even the identities of the general partners. ${ }^{94}$ Significantly, this increase in size, and the

Md 24, 242 A2d 512, 555 (1968); O'Donnell v Sardegna, 336 Md 18, 646 A2d 398 (1994) (standing assumed in dicta).

89 See note 23.

so See, for example, Bourne $v$ Williams, 633 SW2d 469, 472 (Tenn Ct App 1981) (derivative action by member of residential property owners' association permissible, notwithstanding that Tennessee corporate law only explicitly authorized suits by shareholders); Valle $v$ North Jersey Automobile Club, 125 NJ Super 302, 310 A2d 518, 521 (1973) (holding that "shareholder" includes member of nonprofit corporation who brings a derivative action); Atwell v Bide-A-Wee Home Association, 59 Misc 2d 321, 299 NYS2d 40, 41-42 (1969) (holding that a member of a membership corporation may maintain a derivative action against corporation so long as corporation is not excluded from the coverage of Article Six of the General Corporation Law). See also Timothy P. Bjor and James Solheim, 13 Fletcher Cyc Corp $\S 5950$ at 117 (Clark Boardman Callaghan Perm ed 1995) ("The preconditions for a derivative proceeding may not be affected by the kind of corporation.").

91 DeMott, Shareholder Derivative Actions \$ 2:04 at 22 (cited in note 10). But see Revised Model Nonprofit Corporation Act $\$ 6.30$ (ABA 1988) (exposure draft) (granting derivative standing for suits brought by 5 percent or fifty members).

\$2 See, for example, Malone v Superior Court, 40 Cal 2d 546, 254 P2d 517, 519 (1953) (action against officer of nonprofit corporation declared proper without elaboration).

23 Revised Uniform Limited Partnership Act (1976) with the 1985 Amendments, 6A Uniform Laws Annotated $\S 1001$ at 281 (West 1995).

24 See DeMott, Shareholder Derivative Actions $§ 2: 03$ at 17-18 (cited in note 10). See 
widening gap between ownership and effective control, parallels the experience of the larger mutual insurance companies in this century. ${ }^{95}$ Indeed the gap between ownership and control may even be wider in the mutual insurance context since policyholders tend to take little or no interest in the financial health of the company. ${ }^{96}$

\section{Actions by state regulators.}

Enabling statutes are the sole source of an insurance commissioner's power. ${ }^{97}$ The commissioner must perform his duties in the manner authorized by statute and possesses no independent authority to sanction the insurers he supervises. ${ }^{98}$ Since insurance codes do not explicitly grant commissioners the authority to sue derivatively, it follows that they may not properly do so, except when they exercise the broad powers explicitly given to them to rehabilitate or wind up the affairs of insolvent insurers. ${ }^{99}$ Consequently, commissioners appear unable to make a damaged yet solvent insurer whole after a director's breach of duty causes loss; this suggests the need for a derivative cause of action for policyholders.

\section{Rule 23.1}

Federal Rule of Civil Procedure 23.1 $1^{100}$ and similar state

also Comment, Standing of Limited Partners to Sue Derivatively, 65 Colum L Rev 1463, 1479-80 (1965) (Limited partners are similar to shareholders primarily because of separation of managers from investors.).

95 This issue is discussed further in Section III.

${ }_{96}$ See text accompanying notes 24-26.

97 See Ronald A. Anderson and Mark S. Rhodes, 2A Couch on Insurance $2 d$ (Rev ed) § 21.4 at 230-31 (Law Co-op 2d ed 1984 \& Supp 1995).

${ }_{98}$ See Nationwide Life Insurance Co. $v$ Superintendent of Insurance, 16 NY2d 237, 264 NYS2d 541, 545 (1965) ("In exercising the administrative powers of wide breadth given to him, the Superintendent is required ... to follow the statute the way it reads. . . . The statute is the charter of the Superintendent's authority."). See also People $v$ Albany \& Susquehanna Railroad Co., 57 NY 161, 167 (1874) ("The people of this State have no general power to invoke the action of the courts of justice, by suits in their name of sovereignty for the redress of civil wrongs, sustained by some citizens at the hands of others.").

29 See, for example, Uniform Insurers Liquidation Act, 13 Uniform Laws Annotated § 2 at 332 (West 1986 \& Supp 1995) (providing that court must appoint commissioner as receiver); NY Ins Law § 7402 (West 1985 \& Supp 1996) (outlining circumstances in which superintendent may act).

${ }_{100}$ Federal Rule of Civil Procedure 23.1 provides:

In a derivative action brought by one or more shareholders or members to enforce a right of a corporation or of an unincorporated association, the corporation or asso- 
rules are an important yet confusing part of the legal background of derivative suits. Textually, the applicability of the Rule in the mutual insurance context is problematic, yet judicial opinions citing the Rule have failed to discuss whether it poses an obstacle to nontraditional derivative plaintiffs.

The federal rule codifies common law safeguards that had evolved in equity and were aimed at countering strike suits. ${ }^{101}$ Although Rule 23.1 is nominally a rule of procedure, Professor DeMott notes a trend toward viewing the requirements of Rule 23.1 as regulations of substance, controlling who may sue, that federal courts will apply in diversity actions so long as they are not inconsistent with state law. ${ }^{102}$

Despite the ambiguity created by Rule 23.1, it is settled that a plaintiff's capacity to sue is controlled by state law. ${ }^{103}$ The text of the Rule, which is set out in the margin above, plainly presupposes a cause of action for at least some plaintiffs, and yet, being a rule of procedure, it does not actually create one. Thus, Rule 23.1 can govern the procedure followed in diversity cases only where state law independently authorizes the actions. This has spawned a measure of confusion in nonstockholder cases, with the clearest examples occurring when judges evaluate a derivative complaint under Rule 23.1 without first considering whether a substantive cause of action exists. ${ }^{104}$

ciation having failed to enforce a right which may properly be asserted by it, the complaint shall be verified and shall allege (1) that the plaintiff was a shareholder or member at the time of the transaction of which the plaintiff complains or that the plaintiff's share or membership thereafter devolved on the plaintiff by operation of law, and (2) that the action is not a collusive one to confer jurisdiction on a court of the United States which it would not otherwise have. The complaint shall also allege with particularity the efforts, if any, made by the plaintiff to obtain the action the plaintiff desires from the directors or comparable authority and, if necessary, from the shareholders or members, and his reasons for the plaintiff's failure to obtain the action or for not making the effort. The derivative action may not be maintained if it appears that the plaintiff does not fairly and adequately represent the interests of the shareholders or members similarly situated in enforcing the right of the corporation or association. The action shall not be dismissed or compromised without the approval of the court, and notice of the proposed dismissal or compromise shall be given to shareholders or members in such manner as the court directs.

101 See generally ALI, 2 Principles of Corporate Governance § 7.02(a) at 33-34 \& comment e at 39-40 (cited in note 27). The desirability of applying these and other statutory safeguards specifically to a policyholder action is discussed in Section III.B.

${ }_{102}$ DeMott, Shareholder Derivative Actions $\S 4: 02$ at 5 (cited in note 10).

${ }_{103}$ See Kamen v Kemper Financial Services, Inc., 500 US 90, 98-99 (1991) (indicating a presumption of incorporation of state law); Galef $v$ Alexander, 615 F2d 51, 58 (2d Cir 1980) (holding that in diversity suit, state law governs whether stockholder may bring derivative suit).

104 See, for example, Chambrella v Rutledge, 69 Hawaii 271, 740 P2d 1008 (1987). In 
Although Rule 23.1 refers to "shareholders" and "members," the Rule's acknowledgment of standing seems limited to shareholders of corporations, on the one hand, or members of unincorporated associations, on the other. That is, the Rule does not appear to contemplate actions by nonshareholder members of incorporated entities, such as mutual policyholders and members of not-for-profit corporations. ${ }^{105}$ Rule 23.1 and state rules patterned on it have occasionally led courts to assume a cause of action-apparently for any derivative plaintiff-and move quickly to the Rule's requirements. ${ }^{106}$ Indeed, the Elgin case discussed above $^{107}$ is an example of a policyholder suit in which the court treated a state rule patterned on Rule 23.1 as both providing and procedurally regulating the derivative cause of action. The Elgin court explicitly assumed policyholder standing, and compounded its confusion by referring to the requirements of Rule 23.1 as "threshold matter[s] of standing." 108 It can, at least, be argued in mitigation that in Alabama and other states without statutes covering derivative actions, a state rule patterned on Rule 23.1 may more reasonably be read to acknowledge a cause of action for a nonshareholder member than may similar rules in states where legislatures have entered the field. In the latter states,

that case, members of a not-for-profit corporation brought a purported derivative action, alleging breach of duty to the corporation and seeking appointment of a receiver. The Hawaii Supreme Court held that the plaintiffs' cause of action was direct, but expressly noted that the state's version of Rule 23.1, Hawaii R Civ P 23.1, would govern the case. Id at 1014. The court did not mention that Hawaii's statutory provision for derivative actions names only "shareholders," and not "members," as proper plaintiffs. See Hawaii Rev Stat $\S 415-49$ (1985). The court's view, stated obliquely in a footnote, was that "[a] non-profit corporation, of course, has no shareholders, ... [b]ut there is no doubt that the principles expressed here apply to members of non-profit corporations." Chambrella, 740 P2d at $1015 \mathrm{n} 8$ (emphasis added). This is remarkable in light of authoritative commentary stating that members of nonprofit corporations lack derivative standing. See DeMott, Shareholder Derivative Actions $\S 2: 04$ at 22 (cited in note 10) (noting that most states do not permit member derivative suits).

${ }_{105}$ See, for example, Paul P. Harbrecht, The Contemporaneous Ownership Rule in Shareholders' Derivative Suits, 25 UCLA L Rev 1041, 1041 n 2 (1978) (positing that, "[s]trictly read, the Rule only requires an averment of contemporaneous ownership ... [and] operates to bar suits by non-contemporaneous owners"). This strict view suggests that where courts treat Rule 23.1 as providing a substantive cause of action, see, for example, Elgin, $598 \mathrm{~S} 2 \mathrm{~d}$ at 811-12, the Rule could reasonably bar plaintiffs who are neither shareholders in corporations nor members of unincorporated associations from suing derivatively.

${ }_{106}$ See, for example, In re Sunrise Securities Litigation, 916 F2d 874, 887 (3d Cir 1990) (allowing derivative suit by former depositors of savings and loan following unsuccessful demand on receiver).

${ }^{107}$ See text accompanying notes 70-75.

${ }^{103} 598 \mathrm{~S} 2 \mathrm{~d}$ at $810-12$. 
though, Rule 23.1 may tempt judges to skip standing and move on to the Rule's procedural checklist-a problematic leap in any instance where the substantive statute does not expressly provide a cause of action to the instant plaintiff. The Rule may thus exacerbate the tendency of courts to accord standing to nontraditional derivative plaintiffs by facile analogy to more familiar and accepted stockholder actions.

\section{A NEW LEGAL FRAMEWORK FOR POLICYHOLDER DERIVATIVE STANDING}

\section{A. The Importance of Policyholder Standing}

1. Current state regulation may not adequately protect policyholders' interests.

The level of state regulation of insurers is an important factor in evaluating policyholder standing because arguments can be made that the commissioners' authority to remove officers and directors will, if exercised diligently, protect policyholders from at least ongoing management misconduct. Proponents of an administrative remedy will contend that it is less imperfect a check on management than derivative litigation is likely to be, principally because administrative oversight does not yield strike suits. Also, a single administrative procedure is more efficient than the multiple derivative actions that commonly follow corporate scandals. Thus, the argument goes, administrative oversight conserves judicial resources. Indeed, a well supported and diligent commissioner can use his enumerated powers to prod a company to sue or otherwise to seek a remedy from an officer or director whose breach of duty has harmed the company. There are, however, a number of good reasons to believe that a regime that relies solely on administrative enforcement will underprotect the interests of policyholders and perhaps even cost more than private enforcement.

First, the cost of private enforcement may be lower than the cost of administrative adjudication when measured as cost per dollar collected by the enforcer. This is because private enforcement involves profit-maximizing behavior by plaintiffs' attorneys. The plaintiffs' bar will expend resources to investigate wrongdoing and sue for redress up until the point where marginal cost equals marginal return. Administrative agencies, understaffed and constrained by budgetary considerations, cannot find the most efficient enforcement level in this way. Thus private en- 
forcement via derivative actions should be a better remedy so long as the added "deadweight" social costs-stemming mainly from strike suits and trial costs-do not exceed the costs saved by reducing administrative enforcement. ${ }^{109}$ Even if the costs of a private enforcement regime exactly equal the costs of an equivalent level of administrative enforcement, the former is preferable for the simple reason that derivative suit settlements are paid out of private funds (aggregate premiums that directors and officers voluntarily pay for liability insurance) whereas the costs of bureaucratic oversight of insurance management are borne by taxpayers. Thus all taxpayers, with the exception of mutual insurance executives, should favor private enforcement if marginal costs are roughly equal.

Second, even if administrative protection from ongoing (as opposed to past) harms were adequate, expert and well staffed insurance departments, capable of closely observing the activities of all insurers in the state, are becoming increasingly difficult to find. There has long been evidence of understaffing and inadequate resources in state insurance departments, despite ostensibly thorough regulation. ${ }^{110}$ Indeed, in the current political climate, even the most effective state insurance departments will face intense pressure to cut budgets. Moreover, state insurance regulators may be susceptible to lobbying by insurance and other political interests that may not be consonant with the interests of policyholders. Private attorneys general, and plaintiffs generally, are not subject to such influences. ${ }^{111}$

Third, in addition to social cost, private enforcement provides a more just distribution of costs. The statutory arrows in a commissioner's quiver, such as the powers to impose fines, remove directors, seek injunctions, and revoke the company's license, do not remedy losses on a company's balance sheet after damage has been done. Indeed, when an insurance commissioner

${ }^{109}$ See William M. Landes and Richard A. Posner, The Private Enforcement of Law, 4 J Legal Stud 1, 36-38 (1975).

110 See Keeton and Widiss, Insurance Law § 8.1(b) at 935 (cited in note 20) (noting that "state insurance departments have continually been hampered by inadequate funding ... and inefficient personnel"); Woolley and DeGeorge, Policies of Deception?, Bus Week at 25 (cited in note 1) ("[S]tates can rarely muster the resources needed for extensive investigations.").

111 For more on the advantages and disadvantages of private enforcement, see Landes and Posner, $4 \mathrm{~J}$ Legal Stud 1 (cited in note 109); Gary S. Becker and George J. Stigler, Law Enforcement, Malfeasance, and Compensation of Enforcers, 3 J Legal Stud 1 (1974); A. Mitchell Polinsky, Private Versus Public Enforcement of Fines, 9 J Legal Stud 105 (1980). 
fines a mutual company, the resultant payout is a further loss to the company that its members must absorb. Even if a commissioner may be said to have implied authority to sue derivatively on behalf of a mutual insurer-and thereby make it whole-there is no reported case in which a commissioner has done so.

Fourth, there is an externality problem associated with relying on in-state enforcement of the rights of geographically dispersed policyholders. Even when director and officer misconduct violates the laws of the home state, the interests of most company policyholders are likely outside the cognizance of that state's commissioner or any foreign commissioner. That is, in all but the smallest mutuals, only a small fraction of the company's policyholders live in the home state or any other single state. Where the harm to in-state customers is slight relative to that of out-ofstate policyholders, a busy commissioner may elect not to vindicate the rights of the former. Here again, losses to the company will likely go unremedied.

While insurance commissioners can act collectively through the National Association of Insurance Commissioners ("NAIC") to reach settlements for multistate insurer malfeasance, such coordinated action is a new concept and appears ad hoc. ${ }^{112}$ Furthermore, like the commissioners who compose it, the NAIC seeks not to ensure compensation for insurers financially harmed by directors' breaches of duty, but rather to ensure that restitution is made to members of the public suffering "primary" harms, such as losses due to insurance agents' use of deceptive sales techniques. ${ }^{113}$

A final problem with administrative enforcement is the lack of express authority for commissioner derivative actions. New York exemplifies this problem. The legislative history of New York's Insurance Law $\S 108$ suggests that the protection of instate policyholders was a factor in the decision to bar standing for mutual insurance policyholders. ${ }^{114}$ If meaningful "protection" is the goal, however, the state should allow either the policyholders or the superintendent to sue derivatively to redress harms suffered by mutual insurers at the hands of directors and officers.

112 See Prudential in Talks on Accusations, NY Times Section 1 at 36 (cited in note 4) (Metropolitan Life investigation was the first sales investigation coordinated nationwide by state regulators.).

${ }^{123}$ See, for example, id (reporting that task force of state regulators procured agreement from Met Life to refund $\$ 76$ million).

11 For a discussion of New York's interest in protecting state policyholders, see note 84. 
Yet, facially, it appears that neither may do so under the present scheme. The current regime thus underprotects the interests of both policyholders and the company itself.

In light of these considerations, it makes little sense for courts to require policyholder demand upon the state insurance commissioner as a precondition to maintenance of a derivative suit. That courts have done so in the past ${ }^{115}$ indicates a need for legislative or judicial clarification of this aspect of the standing issue. Where insurance codes authorize commissioners' derivative suits on behalf of insolvent companies, a clear indication whether such authorization extends to actions against solvent companies would eliminate litigants' uncertainty.

\section{Mutual policyholders exercise only limited control.}

While the process of proxy solicitation and voting gives stockholders an avenue for redress against wayward management, it is an avenue that policyholders can rarely (if ever) effectively use. As Professors Keeton and Widiss have noted, "the wide dispersion of 'ownership' interests in mutual insurers typically creates a situation of substantial independence for the management[,] ... [which] creates a greater risk that management will go unchecked."116 This gulf between ownership and control is widened by the fact that, although mutual policyholders are entitled to vote in the election of directors, they rarely do so in meaningful numbers. ${ }^{117}$ Nor are there "majority" or "principal" policyholders whose voices are loud enough to constitute a check on management. ${ }^{118}$ Moreover, unlike shareholders of publicly traded companies, policyholders cannot liquidate their interests if management is harming the company. Thus policyholders-whose interests are not marketable-need the protection of derivative actions even more than do owners with market outs.

Similar to the proxy and marketability issues, the limited partnership analogy supports standing for policyholders. First, mutual insurance companies, like limited partnerships, are statutorily created and members derive rights in the first instance

115 See text accompanying notes 48-50.

116 Keeton and Widiss, Insurance Law § 8.5(c) at 968-69 (cited in note 20).

117 See, for example, Pomerantz v Clark, 101 F Supp 341, 345 (D Mass 1951) ("[F]ew policyholders know their voting rights or attend meetings or sign proxies."). See also Hetherington, 1969 Wis L Rev at 1079 (cited in note 23) (noting that only 593 of more than 18 million Prudential Life policyholders voted in the 1968 company elections).

${ }_{118}$ See Hetherington, 1969 Wis L Rev at 1081 (cited in note 23) (noting a general rule that each policyholder has one vote regardless of the number or value of policies held). 
from statute. Second, mutual insurers and limited partnerships manage immense assets and separate ownership from management and control. Third, the ultimate owners of both types of organizations are scattered far and wide. These characteristics in the limited partnership realm moved the Conference of Commissioners on Uniform State Laws to allow limited partner derivative suits. ${ }^{119}$ Because policyholders share these same characteristics, they should likewise be permitted to sue derivatively.

3. Debtor-creditor precepts are not an insurmountable obstacle to standing.

The force of these practical arguments in favor of policyholder standing is limited by the policyholders' creditor-like expectations in buying the company's product. Policyholders do not take out insurance policies to realize "dividends" or augmented "share" value when the company grows. Rather, policyholders buy insurance expecting that the company will compensate them when contractually specified events occur. These expectations parallel those of creditors, or, more precisely, "buyer[s] of protection,"120 rather than those of investors. This attenuates policyholders' ownership interest and reduces their interest in monitoring and constraining management. ${ }^{121}$ That is, the creditor-like interest in receiving a payment following a misfortune can and often will diverge from the long-term interests of the company, rendering the motives behind a derivative action by such a (creditor-like) party somewhat suspect.

To see how policyholders' interests might diverge from those of the company, consider a mutual company that invests in derivative securities as part of its strategy to maximize the long-term return on its capital. A policyholder whose policy covers shortterm risks only (such as the risk that a beach house will be damaged by a hurricane) will fear that market risks associated with derivative securities are jeopardizing the company's ability to pay claims near term; such a policyholder may attempt to sue derivatively on those grounds. ${ }^{122}$ In the hard case, the nearterm risks will be substantial, rendering the applicability of the busi-

11 See text accompanying note 93.

120 Hetherington, 1969 Wis L Rev at 1077 (cited in note 23).

121 Id (arguing that the policyholder "owns nothing but the right to performance by the insurer of its contractual obligation").

122 Such a suit might seek an injunction or, more likely, damages after an adverse movement in the value of the derivative security. 
ness judgment rule uncertain. ${ }^{123}$ If the investment strategy is, nevertheless, in the company's long-term interest (as viewed by management and policyholders, such as whole life policyholders, insuring long-term risks), the company's interests are not aligned with those of the plaintiff policyholder (who cares only that the company remain solvent until next year).

This line of argument, however, need not preclude policyholder derivative suits. It is possible to protect policyholders without sapping judicial resources or encouraging frivolous litigation. The best solution is to specify a minimum number of policyholders who, collectively, represent an ownership interest large enough to justify standing without doing violence to the traditional rule that a creditor may not sue derivatively on behalf of a solvent company. ${ }^{124}$

The creditor analogy is either true and justified in its application to policyholders or it is a formalistic proxy for the real complaint-that derivative litigation is fraught with defects and should be limited where there is an alternative means of checking management misconduct. Specifying a minimum number of policyholder-plaintiffs solves both the formalistic and the defectdriven concerns. ${ }^{125}$ First, above a certain numerical threshold, a group of policyholders must be considered owners for the purposes of controversies with management. While each policyholder has a tiny ownership stake, there are no other owners available to pursue the ownership interests against management (as there might be in a corporation with a more complex capital structure). To argue that policyholders may not sue in groups as owners runs counter to the idea that real persons must be the ultimate owners of corporate property. ${ }^{126}$

Second, requiring a minimum number of policyholder-plaintiffs overcomes the primary defects of derivative litigation by requiring that plaintiffs' attorneys contact a sizeable number of individuals and convince them that a given complaint against

${ }^{123}$ The business judgment rule insulates good faith management decisions from the interference of derivative actions. See generally Harry G. Henn and John R. Alexander, Laws of Corporations and Other Business Enterprises $\S 366$ at 1070-73 (West 1983). This example assumes the risks to be such as may cause a judge to balk in applying the rule to an insurance company.

${ }^{224}$ This issue is addressed further in Section III.C.

${ }^{325}$ For an example of such a threshold, see Revised Model Nonprofit Corporation Act § 6.30 (cited in note 91) (allowing derivative action by any member or group of members owning 5 percent or more of the voting stock, or any group of fifty or more members).

${ }^{126}$ For a discussion of the policyholders' ownership interests, see text accompanying note 52 . 
management is legitimate. This presents a cost threshold below which no suit will be brought; plaintiffs' lawyers will only invest resources to meet the threshold where the value of the suit is substantially above it (thus presenting a profit opportunity for them). Because the value of the suit (how much was lost) is distinct from the merit of its allegations (whether management wrongfully caused the loss), it is still possible that high-value suits of low merit will be filed. But the up-front cost should lead potential plaintiffs to fear the possibility of losing at the summary judgment stage (and losing the time and money invested), a possibility that will in turn diminish the expected value of any anticipated settlement enough to cause them to shy away in the first instance. Simply put, strike suits-driven by the desire for quick, nuisance-value settlements-will be discouraged by the up-front costs of bringing suit. ${ }^{127}$ Thus, such a regime permits the owners of mutual companies to benefit from the services of the plaintiffs' bar, including active (yet cost-efficient) enforcement of management duties and the deterrence of future breaches that results from such enforcement, while also providing a disincentive to strike suits.

Although this proposal offers the best way to regulate the actions of mutual insurance managers and directors, two further problems must be addressed: first, the legal grounding for this cause of action, and, second, a mechanism by which the courts can discourage and deal with frivolous litigation.

\section{B. Legal Bases for Policyholder Derivative Actions}

Aside from the form of the derivative suit, the question remains whether plaintiffs may sue at all in the absence of an express state statutory provision. Legislative clarification of this issue would relieve judges of the task of twisting corporate statutes-which in terms give standing to shareholders only-in order to apply them to nonshareholder actions. ${ }^{28}$ Indeed, if legislators view provisions for derivative actions by policyholders as

127 One side effect is that low-value suits of high merit will also be discouraged. A ready solution to this problem would be to exempt from the minimum-joined-parties requirement actions where the amount in controversy is low.

${ }^{123}$ See, for example, Bourne v Williams, 633 SW2d 469, 472 (Tenn App 1981). In Bourne, the court applied Tenn Code Ann $\S \S 48-718$, which grants a derivative cause of action to "shareholders," to an action by a member of a nonprofit corporation. The court stated that " $[w]$ hile this Court would prefer that specific statutory authority be spelled out more clearly, nonetheless, it is not without adequate precedent to see to it that the plaintiffs at least have their day in court." Bourne, 633 SW2d at 472. 
out of place in chapters relating to business corporation law, ${ }^{129}$ it is doubly ironic that courts have been called upon to contort sections of corporation codes in order to let nonshareholder suits proceed.

When presented with policyholder derivative actions, courts should unambiguously decide that plaintiffs do or do not have a derivative right of action as members of the company-even if the parties do not press the issue on the court. This will require insurance-specific analysis of current statutes and an explication of the defects of the existing judicial opinions on the subject. Certainly, legislative clarification would be preferable in all jurisdictions where the legislature has entered the field, Wisconsin and Connecticut excepted. ${ }^{130}$ But until such clarification occurs, and in states where the courts alone regulate derivative suits, judges should examine the similarities and differences between stockholders and policyholders (as well as related questions) and conclude that policyholders, if acting in sufficient numbers, are entitled to sue derivatively for the same reasons that other equity owners are allowed to do so.

\section{Necessary Safeguards Must be Adapted from Corporation} Law

Minority shareholder suits have long been controversial, and derivative suits provide no guarantee that the proceeds will flow to the shareholders. Indeed, plaintiffs' lawyers are often the real parties in interest. Derivative suits rarely get past the demand requirement and, when they do, they do not always set matters right on the company balance sheet. ${ }^{131}$ These and other short-

129 See, for example, Consultant's Report to State of New York, Joint Legislative Committee to Study Revision of Corporation Laws 30 (1963) (on file with U Chi L Rev) ("Recommendation (c)(i) of this Report is that references in Section 63 [providing for reimbursement of litigation expenses of corporate officials] ... to non-stock corporations, savings banks and mutual insurance companies, be omitted in the proposed section. Since the proposed section is to be part of the Business Corporation Act, inclusion of the stated references would be out of place."). But see New York State Legislative Annual, 1964 at 148 (cited in note 84) (applying parts of the BCL to insurers).

130 See notes 77-80 and accompanying text.

131 See, for example, ALI, 2 Principles of Corporate Governance pt VII, ch 1 at 10 (cited in note 27) (Empirical data suggests existence of a substantial conflict of interest in derivative litigation between plaintiffs' attorneys and their ostensible clients, the shareholders, which causes a high incidence of derivative action settlements involving minor procedural changes but significant attorney fees.); Bryant G. Garth, Mene H. Nagel, and Sheldon J. Plager, Empirical Research and the Shareholder Derivative Suit: Toward a Better-Informed Debate, 48 L \& Contemp Probs 137, 145-47 (Summer 1985). 
comings of derivative litigation have long been recognized and have received ample attention from commentators. ${ }^{132}$ Still, the policies that support minority shareholder derivative actions have prevailed over the risks and defects of derivative litigation, making derivative suits an accepted means of policing the conduct of corporate management.

In the past half century or so, as the perils of derivative litigation have become clear, ${ }^{133}$ legislatures have adopted security-for-expenses statutes and other safeguards to ensure the bona fides of derivative plaintiffs. Beyond these mechanisms, state legislatures and the Federal Rules of Civil Procedure have tightened common law strictures. ${ }^{134}$ Rule 23.1 lists these strictures, ${ }^{135}$ a number of which existed prior to the promulgation of the Federal Rules. This Section addresses the Rule's requirements seriatim, discussing their applicability in the mutual insurance setting.

While policyholders may sue derivatively in certain jurisdictions, these jurisdictions may not have safeguards specially tailored to such suits. Moreover, courts may be unable to apply existing statutory safeguards because, by their terms, they apply only to stockholder suits. For example, once standing is accorded (or assumed), stockholder plaintiffs may be required to post security for expenses, including attorneys' fees. Nineteen states have statutes imposing such a requirement, with the amount of security generally left to the discretion of the court. ${ }^{136}$ With some exceptions, these statutes apply only if a plaintiff's holdings of the company's stock fall below a certain level. ${ }^{137}$ These statutes, however, and the general security-for-costs statutes in force in forty-

132 See, for example, John C. Coffee, Jr., The Unfaithful Champion: The Plaintiff as Monitor in Shareholder Litigation, 48 L \& Contemp Probs 5 (Summer 1985); Roberta Romano, The Shareholder Suit: Litigation Without Foundation?, 7 J L Econ \& Org 55 (1991).

${ }^{133}$ For example, empirical findings have indicated that (1) plaintiffs' holdings tend to be nominal, (2) litigated victories are seldom achieved, and (3) private settlements in which the corporation receives nothing are common. Franklin S. Wood, Survey and Report Regarding Stockholders' Derivative Suits 112-15 (NY Chamber of Commerce 1944). See also ALI, 2 Principles of Corporate Governance pt VII, ch 1 at 10 (cited in note 27).

${ }^{134}$ See ALI, 2 Principles of Corporate Governance pt VII, ch 1 at 9 (cited in note 27) (noting that state legislatures tightened common law defenses).

135 See note 100.

136 See DeMott, Shareholder Derivative Actions § 3:01 at 1 (cited in note 10).

137 Most of these statutes are patterned after the Model Business Corporation Act Ann $2 d \S 49$ (West 1971) (providing that the corporation may require a plaintiff holding less than 5 percent of outstanding shares, or less than $\$ 25,000$ in value, to post security for costs likely to be incurred during the course of litigation, including attorneys' fees). 
one states, ${ }^{138}$ are available only against specified stockholderplaintiffs. Because policyholders are not stockholders, courts have declined to compel policyholders suing derivatively to post security. ${ }^{139}$

The absence of provisions for security-for-expense deposits in policyholder derivative actions might be addressed in two ways. The first option is a statute. Wisconsin's 1973 law, currently unique, provides that defendants may require derivative plaintiffs to post security if they account for less than 3 percent of the members of a nonstock company. ${ }^{140}$ This provision, however, sets the threshold too high. While there should be a level above which a group of policyholders suing derivatively should be free from security-for-costs requirements, a derivative action by 3 percent of the policyholders in any but the smallest mutual companies will be rare, since never do more than a fraction of a percent participate in company affairs. ${ }^{141}$ Thus a lower threshold, perhaps a fixed number of one hundred or so policyholder-plaintiffs, seems proper. If this level is too strict (for example, in cases involving very small mutual insurance companies), a judge should be able to waive the security requirement for belowthreshold plaintiffs in cases where the cause of action appears meritorious. The second way the security-for-expense problem might be addressed in the policyholder suit context is via the creation or modification of court rules ${ }^{142}$ giving judges the discretion to require a plaintiff to post security when they deem it appropriate.

With some modification, courts can and should apply the requirements of Rule 23.1 to policyholder derivative actions. Requiring that the complaint be verified, ${ }^{143}$ for example, has a

138 DeMott, Shareholder Derivative Actions § 3:03 at 29-30 n 1 (cited in note 10) (citing state statutes).

139 See, for example, Imberman v Alexander, 203 Misc 576, 116 NYS2d 609, 610-11 (NY Sup Ct 1952) (In mutual insurance derivative action, defendant could not compel plaintiff to post security for expenses under statute requiring security only from shareholders or holders of voting trust certificates.).

140 Wis Stat Ann $\S 181.295$ (4). For the Wisconsin statutes establishing the cause of action, see note 80. For a more absolute threshold, see NY Not-for-Profit Corp Law § 623(a) (McKinney 1970 \& Supp 1996) (providing that plaintiffs may bring a derivative action only if they represent 5 percent or more of the holders of the corporation's capital certifcates).

141 See notes 117 and 146.

142 See DeMott, Shareholder Derivative Actions $\S 3: 03$ at 38-40 n 24 (cited in note 10) (citing local federal court rules governing security for costs).

143 When a derivative complaint is verified, the attorney of record swears that he has made a good faith investigation of the allegations in the complaint and that the allega- 
prophylactic effect against strike suits since it requires some level of prescreening by the plaintiffs' attorneys. ${ }^{144}$

In addition, courts should require contemporaneous ownership as a prerequisite to derivative standing, despite conflicting case law concerning whether a company may defeat standing by canceling a plaintiff's policy. ${ }^{145}$ The terms of the insurance contract govern the policyholder relationship in the first instance, and courts should be wary of holding that an insurer may not trump standing by exercising its right not to renew in these circumstances. Moreover, a strict ownership-at-filing requirement would provide a useful bright line, albeit at the risk of shutting out plaintiffs whose policies happen to expire during the process of making demand, just prior to filing a complaint.

The requirement of Rule 23.1 that the derivative plaintiff attempt a demand on the members when the board refuses to bring the action (or give reasons for not making the effort) should not apply to policyholder actions. Judges should, as a matter of course, exercise the discretion Rule 23.1 gives them to excuse such a demand, even if plaintiffs fail to make clear their reasons for not making it. As noted earlier, insurance policyholders generally do not receive or respond to proxy statements and do not otherwise participate in the voting process. ${ }^{146}$ Thus, for courts to require that a demand be made on all policyholders will, in most cases, be unreasonable because the costs of communication will virtually always be prohibitive. ${ }^{147}$

This is not to say that courts should not require policyholders to win a certain number of their kind over to the cause. To the contrary, policyholders' attenuated ownership interests militate in favor of requiring that some number of them be joined as plaintiffs. As noted with reference to the security-for-expenses issue, requiring a number on the order of one hundred policy-

tions are true on information and belief.

14 See Edmund C. Ursin, Note, Verification as a Safeguard Against Abuse of Stockholders' Derivative Suits, 18 Stan L Rev 1221, 1222-23 (1966) (discussing impact of verification requirement on strike suits).

${ }^{145}$ Compare Elgin, 598 S2d at 813 (Ex-policyholder may be equitably excused from ownership-at-filing requirement.), with Lower, $502 \mathrm{NE2d}$ at 840 (Insurer may defeat standing to sue derivatively by not renewing plaintiff's policy.). See text accompanying notes $67-72$.

${ }^{146}$ See Hetherington, $1969 \mathrm{Wis} \mathrm{L}$ Rev at 1079 (cited in note 23) (" $[\mathrm{P}]$ olicyholder participation is minimal, and the [voting] procedure has far less . . . significance than it does in a widely held stock corporation.").

${ }^{147}$ See, for example, Elgin, 598 S2d at 817 ("Even one written formal demand by mail upon more than 373,000 mutual company policyholders would have been prohibitively expensive and time-consuming."). 
holder-plaintiffs will deter strike suits without imposing communication costs that may foreclose the remedy. While any number arrived at without extensive empirical research must be considered tentative, it seems reasonable to assume that one hundred policyholders will not support a strike suit. ${ }^{148}$ Furthermore, the collective interest of one hundred policyholders seems sufficient to overcome concerns as to each individual policyholder's attenuated stake in the outcome of the controversy.

Finally, Rule 23.1's requirements of fair and adequate representation and of judicial approval of settlements are entirely appropriate in the mutual insurance setting. The uncertainty associated with the standing question creates a risk of collusive settlements that is greater than in the stock-corporation context. Defendant directors and officers will be inclined to settle for strike suit money rather than risk judicial recognition of policyholder standing. Mandatory judicial approval of such settlements coupled with diligent evaluation of settlement proposals ought to weed out those strike suits that get past the minimumjoined-plaintiffs and "fair and adequate representation" hurdles.

\section{CONCLUSION}

Two major policies favor derivative suits: the concept of private attorneys general and the right to compel proper use of corporate assets. These policies apply as strongly in the mutual insurance setting as they do in the business corporation context. Judges and legislatures must consider whether the policyholders' attenuated ownership interest should, in view of state regulation and the well known risks of derivative litigation, tip the balance against policyholders.

As this Comment has argued, private policyholder enforcement probably surpasses state regulation in terms of efficiency and efficacy. A requirement that policyholders bring derivative actions in substantial groups permits the owners of these companies to harness the energy of the plaintiffs' bar while tempering its negative tendencies. Because numerous policyholders provide a tangible equity interest, the plaintiffs' interests are more likely to be aligned with the entire body of members. Such a group action requirement, when coupled with insurance-specific adaptations of procedural safeguards developed in the corporate context, would support policyholder standing and allay concerns as to

148 Over time, experience may point to a higher or lower number. 
strike suits. Moreover, it would not run afoul of the policies animating the rule against creditor derivative suits.

The status quo systematically underprotects policyholders. Members do not meaningfully govern mutual insurance companies. Insurance commissioners lack authority to bring derivative suits on behalf of solvent companies. State insurance departments are too inefficient and underfinanced to regulate effectively. Until one or more of these factors changes substantially to better protect policyholders' interests, courts should explicitly recognize and carefully regulate derivative actions in the mutual insurance context. 
